\title{
The Migratory Trajectories of the Post 1994 Generation of African Immigrants to South Africa: An Empirical Study of Street Vendors in the Cape Town Metropolitan Area
}

\author{
Cyprian Y. Lapah \\ Dr. Robertson K. Tengeh \\ Faculty of Informatics and Design, \\ Cape Peninsula University of Technology, South Africa. \\ E-mail: rtengeh@yahoo.com
}

Doi: 10.5901/mjss.2013.v4n4p181

\begin{abstract}
The aim of this study was to explore the spatial migratory trajectory of migrants to South African since 1994 with special emphasis on street vendors of African origin. The study adapted a mix research approach in which a survey questionnaire, focus group discussions, personal interviews, and observation were utilised to collect and analyse the data. The results of the study revealed that the migration of Africans into South African cities increases sharply as the years go by. The number of migrant street vendors almost doubled between 1993 and 2002 and almost tripled between 2003 and 2007 while the marked increase actually started in 2004. The stable political atmosphere probably played a role in making South Africa an attractive destination for many migrants especially from the African continent. The actual migratory trajectory of street vendors shows that most of the vendors come to South Africa directly from their countries of birth. Of the 208 respondents interviewed, only 90 passed through other countries or have lived in other countries apart from their countries of origin. Inter-country comparism revealed that vendors from Cameroon, Congo Brazzaville and Nigeria have the least experience in migration as $82.4 \%, 66.7 \%$ and $63.2 \%$ of vendors from these countries respectively have never stayed in any other country other than their countries of birth even in the course of their migration to South Africa. This implies that their migratory trajectory to South Africa is a direct one. On the other hand vendors from Malawi as well as from Somalia show a high experience in migration as $87.5 \%$ and $60 \%$ respectively have migrated at least once before coming to South Africa. In terms of the means of transport that these immigrants use to reach their country of destination, it was noted that $50 \%$ of the migrants entered the country by direct flight into the country. The prospect of further migration of the vendors was largely positive with $76 \%$ of them indicating their intention to move with only $24 \%$ indicating their intention to stay permanently in the country. This notwithstanding, a significant proportion indicated their willingness to return to their home countries one day.
\end{abstract}

Keywords: spatial migratory trajectory, African immigrants, South Africa, street vendors,

\section{Introduction}

Migration has been perceived by many to be a long-term feature of the African continent and that it is in many areas closely linked to local development. According to Sorensen (2006), intra-national, rural-to-urban migration and crossborder migration into neighbouring countries still constitute the bulk of sub-Saharan African movements of migration, even though inter-regional and international migration is on the rise. Sorensen (2006) believes that an estimated 20-50 million migrants were thought to be residing in Africa in 2004, whereas the estimate for international migrants of African origin was 16.3 million. Of these, the majority are refugees. It was projected that by 2005 , one in ten Africans will be living outside their countries of origin.

Generally, migration has been on the increase with the improvement in transport and communication infrastructure (De Haas, 2009; Schapendonk, 2012). In the same light, migration into South African cities took a different dimension especially after the fall of the Apartheid Regime (Peberdy and Rogerson, 2000). The collapse of the Apartheid Regime in the early nineties meant the rekindling of cooperation between South Africa and its neighbours as well as the rest of the African continent. According to Peberdy and Rogerson (2000), this new trend of immigrants coming into the country mostly from the Southern African Development community (SADC) region and the rest of Africa as opposed to earlier immigrations which were mostly from Europe and Asia has given rise to a "New Immigration Regime". Despite the country's restrictive policy on African immigrants, their numbers have been on the increase. 
The fall of Apartheid in South Africa also led to the reinsertion of South African cities in the informal trade networks (Crush \& McDonald, 2000) and street vending was of particular interest. The acknowledgement of formal trading in general and street trading in particular by the post apartheid government and couple with other factors lured or pushed people to this sector. Under this circumstance one may suggest that a majority of the African immigrants in this sector were either pushed or pulled. The forces at work may include the Country's immigration policy which is aimed at making the stay of these particular immigrants temporary, thereby hindering their formal employment and the shrinking of major employing sectors such as mining and agricultural sectors (Crush \& McDonald, 2000) and consequently the scarcity of jobs.

Some of these immigrants are street vendors in South Africa. Many of them especially from other African countries find it as a suitable means of survival. Coming from different socioeconomic, cultural and political backgrounds, these immigrants resort to different ways of adaptation to integrate in the city and sustain their livelihoods.

Migration is an area of study that has been significantly researched and approached from different angles. A cohort of scholars have looked at the pull and push factors of migrations, others have concentrated on the effects of migration on the host and the destination countries. Yet another group of scholars have focused on the spatial migratory process or what we describe in this paper as the "entry, exit and in-between processes" that characterize migration. This notwithstanding the magnitude of the research done on the latter is limited and more so when it comes to African countries as migratory destinations and South Africa is no exception.

\subsection{Aims of the Study}

The aim of this study is investigate the spatial migratory trajectory of migrants to South African since 1994 with special emphasis on street vendors of African origin. Specifically, we look at which African countries are "knocking" on South African's "doors", how they get in and their exit intention. questions:

In an attempt to facilitate the achievement of the foregoing aims of the study, we probe the following line of

- What has been the most significant post 1994 migratory periods for South African with respect to African immigrants?

- Do African immigrants make stopovers on their way to South Africa?

- Which African countries are more likely to have their emigrants make compulsory stopovers in other countries on their way to South Africa?

- What is the preferred mode of transport for African immigrants?

- Is the preferred mode of travel to South Africa consistent across the countries studied?

- What are the return intentions of the post 1994 generation of African street vendors in South Africa?

\section{Literature review}

The usage of the term "migration" describes the movement of people from one place of residence to another within or beyond a territorial area either temporarily or permanently. Migration is a phenomenon that spans decades and its dynamics has evolved over the years, as may be indicated by the changes in the sending and receiving countries as well as the migratory means for instance. European countries were the primary destinations for African immigrants until the recent past (Massey, Arango, Hugu, Kouaouc, Pellegrino \& Taylor, 1993). In recent years, there has been a reverse trend with some African countries and particularly South Africa witnessing a significant increase in the number of African immigrants. Although, the north is still the preferred destination, more and more sub-Saharan Africans are turning South (South Africa) in the search for "greener pastures".

Turning "South", as an emerging trend can be associated with a number of factors. Firstly, the establishment of a new democratic order facilitated integration and cooperation with other countries and more importantly African countries. Secondly, most European countries have tightened their borders amidst the global economic downturn. Although, South African has done the same and wish to do more, they seem to lack the resources to be as effective as their European counterparts. Thirdly, globalization enhanced by advances in telecommunications has promoted migration at all levels (Schapendonk, 2012). For instance, information sharing facilitates the formation of efficient migratory networks that feeds subsequent migrations. And this concurs with Massey's network theory (Massey et al. 1993; Light, Bhachu, \& Karageorgis, 1989). 


\subsection{Migratory Trajectories}

Since most migrations occur following particular networks, there is no doubt that the migratory trajectory would also be influenced by these same networks that enable the persistence of migrations as Veronica de Miguel and others put it "a better comprehension of the itineraries and strategies of the population and the association to the social networks that exist in the place of origin and destination allows for a better comprehension of the migration phenomenon" (De MiguelLuken et al., 2009). The notion of 'migration trajectories' has not received much attention from researchers but can have a strong impact on the distribution or settlement patterns of the immigrant population as well as the activities they carry out or the way they insert themselves in the host country.

A migratory trajectory in itself would be shaped by social capital through social networks. Hence, the decision as to which means or ways are better might not be the sole decision of the migrant him or herself but a collective decision especially by those who are either resident or had been to the destination country before or know more about it. In the study of migratory trajectories of immigrants in Spain, Veronica De Miguel-Luken and others identify two main types of migratory trajectories namely 'direct' and 'indirect' trajectories. Their findings reveal differences in terms of absolute numbers and trajectories between regions and between nationalities. There are also differences in sex and even age in the migration trajectories of foreign nationals in Spain. Morocco had the highest population of foreign nationals in Spain with $12 \%$ while $84 \%$ of them had direct trajectories to the country. In another study, $18.4 \%$ of men as against $13.4 \%$ of women in Spain had stayed in another country before arriving in Spain (Solana Solana et al., 2009 cited in De Miguelliken et al., 2009).

Migratory Trajectory refers to the means used by immigrants in the process of their migration and insertion in their places of destination. Four types of trajectories have been identified namely: spatial, social, network and economic trajectories. For the purpose of this study we look at the spatial trajectories of African street vendors in South Africa.

Once migrants reach their destination country, they are confronted with the problem of sustaining their livelihoods. One of the ways of insertion is by becoming entrepreneurs. As Pécoud affirms, "entrepreneurship is an important means of incorporation of immigrants in their host countries" (Pécoud, 2005). The migration or social networks facilitate immigrants to become entrepreneurs in their host country. Light and others identified three ways by which social networks help fellow migrants in investing in their host countries (Light et al., 1989).

Firstly, networks facilitate the supply of low-cost labour to immigrant entrepreneurs who have established ethnic enterprises. This happens as immigrants tend to employ mostly fellow immigrants in their enterprises probably due to the faith they have on them as people with a common objective but also as they would often demand lower rates compared to locals (Tengeh et al, 2011).

Secondly, networks provide the necessary information to entrepreneurs as well as would-be immigrant entrepreneurs. This information covers issues like how and where to start a business, the pricing policies of the country, the best sectors to invest, dealing with public bureaucracies and possible obstacles in the various possible ventures (Tengeh et al., 2011). This information is often concealed to people who do not form part of the social or migration network.

Thirdly, through migration networks, immigrant entrepreneurs can get access to various forms of aid. Hence initial training and capital can easily be gotten through these networks. Immigrants easily get apprenticeship and start-up capital through associations and family members (who constitute this network).

One may now ask the question "why do immigrants engage in informal enterprising?" Many reasons have been advanced by different authors to explain immigrants' involvement in business activities (both formal and informal) in their host countries. Among some of the reasons, one can generally identify:

- The high unemployment levels among the immigrants compared to natives. Various studies have shown that there are always disparities in employment levels between nationals and immigrants (Zuberi et al., 2005; Tengeh et al , 2011). This is further compounded by the discriminatory employment policies governing employment in most receiving countries where the natives are often favoured. Another contributory factor to these high levels of unemployment is the fact that most immigrants lack or are unable to procure the necessary legal documents that can permit their employment in the formal sector of their host country (Polzer, 2008).

- Immigrant entrepreneurs easily find some sectors abandoned by the natives such as petit trade (hawking) like street trade in spices and newspaper stalls. This has been the situation in most European countries like Britain and France (Waldinger, 1994 cited in Pécoud, 2005).

- Due to the increasing need for immigrants to acquire certain goods and services specific to the immigrant 
population, immigrant entrepreneurs emerge to supply these goods and services that are in high demand and common within the immigrant community. These include especially foodstuff and certain services like conveyance of remittances.

- $\quad$ Natives sometimes move out of immigrant suburbs with their commercial activities leaving the migrants with no option than to establish their own ethnic economies. This is further favoured by the concentration of immigrant population and the development of strong social networks (De Miguel-luken et al., 2009).

The above factors may apply to both the formal and informal sectors of the economy. Immigrants' involvement in the informal sector has just recently attracted some interest from researchers especially in the developed world. Informal trading has earlier been seen as a thing of the developing world (Pécoud, 2005). The informalisation of economies of developed nations is a replication of the situation that has long prevailed in the developing countries though it is not necessarily the source of informal sector in the developed world. The cause is probably the weakening of the production sector and the growth of the tertiary sector (Pécoud, 2005). This probably leads to the polarization of the society between the rich and the poor. The poor easily find livelihood in the informal sector. Hence poor immigrants easily find the informal sector as a breakthrough in their search for a "new life". This of course is facilitated by the social networks of which they form part. Factors that contribute to immigrants' insertion in the informal sector of their host countries include:

- The low capital needed to start the business. In most cases provided by some relations (friends, family members and ethnic associations).

- $\quad$ Another encouraging factor may be the legal framework surrounding the operation of this form of business. Most often, there is little or no bureaucratic work needed to go through in order to start up business in the informal sector. This therefore encourages most immigrants who status in the host country is not stable in the host country or even not legal.

- The development of partnerships between the formal and informal sector also favours the insertion of immigrants in the informal sector. A case in point is the development of partnerships by textile companies in Britain with immigrant street vendors (Pécoud, 2005).

While some immigrants enter into business in their host countries as big entrepreneurs, it is true that a majority of immigrants from developing countries are often involved in informal trade especially street vending owing to the fact that they come from poor backgrounds or might have gone through major setbacks in their lives in their home countries.

\subsection{Street vendors as part of the informal sector}

Street vending is fast becoming a global phenomenon. Though it is mostly practiced in developing countries, it is not uncommon in the developed world. Millions of people earn their livelihood by selling on the streets. A study in 1990 showed that about 275000 people were engaged in street vending in Mexico City alone (ILO, 2002). In another study in India, $7 \%$ of those employed in the formal sector in one city where street vendors (Charmes et al. in ILO, 2002). Another study done by Muiruri Philomina (2010) in Nairobi-Kenya showed that $97 \%$ of the female population depended solely on street vending for their livelihood.

In developing countries especially in Africa and Asia, street vending represent between 73 and 95\% of employment in trade and contribute about 50 to $90 \%$ to the GDP in some countries. In South Africa, the 2000 Labour Force Survey estimated that there were 445000 street vendors in the country while street vending accounted for $26 \%$ of value added in trade in 1999 (ILO, 2002).

A street vendor can be defined as a person who offers goods or services for sale to the public without having a permanent built-up structure and not being captured by the tax system of the geographical area in which he or she trades. Street vendors may have semi-permanent trading structures or mobile. They range from people who sale manufactured goods through providers of services like barbing and shoe repairing to those acting as agents of shops and well-established firms (in the formal sector).

\subsection{Demographic Characteristics:}

Many studies have shown some similarities as well as differences in the demographic characteristics of street vendors.

There seems not to be a general trend in terms of age of vendors worldwide. However certain localities show some common trends in the ages of street vendors. There exist some similarities in studies done in Johannesburg CBD and Metropolitan Durban with $77 \%$ of most street vendors between the ages of 25 and 49 years. However there were many 
more men than women entering into street trade though many more men also left the activity earlier for other employment opportunities (Lund, 1998).

Gender disparity is also a major characteristic of street trade with more men than women engaged in the activity in some areas and the reverse is true in other localities (ILO 2002). The activity is also very gender-segregative with respect to the numbers and types of goods or services sold in some localities. In India for example, there are more men engaged in street vending than women (Kamala et al. 2007). Another example of this feature can be seen in the study of street vendors in Lesotho (Tanga, 1994) where women specialised in the sale of perishables and foodstuff while men dominated in the sale of manufactured products. The Johannesburg and Durban Metropolitan area studies confirmed the gender disparity nature of street vending where $40 \%$ of women in the Durban surveyed sold fresh produce with more women than men in both studies working as employees or as agents (fronts). Both studies also showed little diversification in the types of goods or services sold (Lund, 1998). According to the ILO report of 2002, the proportion of female vendors seem to vary from country to country and even between regions and towns of the same country. The percentage varies from $2 \%$ in Tunisia to $81 \%$ in Benin. These disparities are also seen in the value added to trade especially in developing countries. Many factors can be responsible for these disparities. These may include the cultural differences between localities, the policies and laws relating to street vendors and the level of democracy. Women in South Africa are also more concentrated in the sale of foodstuff and manufactured goods (Lund, 1998).

There seems to be no general trend concerning the marital status of street vendors. In other words, the marital status does not have any relationship with street vending except in some areas where cultural practices bar the married women from carrying out any economic activity which is very rare nowadays. In the study in Durban Metropolitan area done in 1998, about one quarter of both men and female surveyed were married while in Isipingo, the proportion was $40 \%$ of the vendors being married and $56 \%$ being single (Lund, 1998).

\subsection{Policy on street vending in South Africa}

Policies governing street trade in South Africa has evolved with time. It can be divided into two scenarios namely the situation during the Apartheid era and the post apartheid era. The legacy of apartheid has had a huge impact on the development of the informal sector in general and street vending in particular. Policies during the apartheid era were aimed at restricting movement and activities (including business activities) of the black (poor) community. This was done through a series of acts. One of those acts was the Native (Urban Areas) act of 1923 which restricted blacks from residing in urban areas (let alone operating any business venture). They (blacks) could only do so if they were recruited to work for the "white men" residing in these areas. This was later modified by 'move-on laws' which stipulated that any street vendor had to be strictly mobile (changing his locations at given time intervals). Other acts which had the same consequences of stifling self-employment include the 'Group areas act' and the 'Development and Trust and Land Act' (Lund, 1998). After much resistance from the national and international communities with the official abolition of apartheid, these acts were discarded and replaced by the 'Business act' in 1991 which removed all the barriers to business in general and informal trade in particular. This was followed by the 'Small Business act' in 1995 that actually aimed at promoting and encouraging the development of the informal sector through the provision of financial services to small enterprises and incorporating the sector in urban planning policies through a participative approach. Policies regarding street vending in urban South Africa have henceforth been enacted by provincial legislatures and municipalities in line with national policies on urban development. One of the cases is the Johannesburg 2030 Development Plan whose implementation started in 2005. In its quest for a "world-class city" the city of Johannesburg embarked on a series of measures in 2005 aimed at "cleaning" the city streets of informal vendors and making the city more attractive for investment. The plan was intended to boost investments in the city by ensuring that hawkers were kept off the streets in some areas which affected about 15000 informal vendors in 2005. The city officials assert that street vendors are "a brake" on growth as new investments are hindered by their activities despite also asserting that the council of Johannesburg is not opposed to informal trading but to "illegal trading".

In a bid to mitigate the consequences of the Plan, the Council constructed 8 markets to accommodate the street vendors. This meant that thousands of these street vendors had to be relocated in these vendors markets. This created another problem as vendors were not satisfied with the relocation as this meant the narrowing of the market. This is because they were confined to particular areas remote from the busy city centre where they located their businesses at strategic locations to give a maximum view of their goods to passers-by. Vendors also complained of overcrowding in these markets. This of course seriously affected their sales and profit margins and hence their livelihood. However, one city official could admit the consequences by saying "an African city cannot be like New York" (Vicki, 2005). 
In view of all the negative impacts of urban policy implementation on the weaker population of the urban frame, many authors and groups have been quick to point out the need for street vending to be incorporated in the mainstream economy and to call for the respect for the rights for livelihood of the poor members of the society (Nontyatyambo, 2005). Hence any attempt of meeting the millennium development goal on poverty should be through strengthening the informal sector and street vending in particular which is the source of livelihood for a majority of the poor.

\subsection{Migrations routes, methods and motivation}

Migrants use numerous land, sea and air routes to reach their desired destinations in Africa and Europe (De Haas, 2009). Assuming migration is a well thought process that sometimes involves the whole family and to some extent the whole community, one would want to think that the the mode and means of transport are dynamics that are all factored into the decision making process. Numerous factors may be taken into consideration when choosing the means and mode of transport. Finance may be one of the most influential factors when it comes to determining what means of transport to use, given that they various means of transport available to carry different price tags with pricing closely associated with availability, time savings, safety and other indirect factors. The aeroplane for instance is the most expensive, but time saving and safer. However, its cost, non availability and requirements make it is the least used in most African countries. From a host country perspective, this may be the preferred means for immigrants as the host government can monitor the number entering or leaving the country.

Restrictive immigration policies and intensified migration controls have led to a growing reliance on overland routes, although migrants who can afford it make at least part of the journey to North Africa by aeroplane (De Haas, 2009).

\subsection{Transition migration}

Transit migration is a Eurocentric notion of a migratory phenomenon which has developed since the beginning of the 1990 s as a result of the end of bipolarity and the fall of communism in the Eastern block (Nielsen, 2008).

Not all migrants have the privilege to go directly to their country of destination. For numerous reasons migrants have to transit through other countries as they make the arduous journeys to the "promise land". While the need to transit may be voluntary for some, others do not have a choice. Factors such as lack of time, entry visa, finance and so forth may make it practically impossible for these migrants to directly enter their country of destination. For those who make these "stopovers", factors such as the need make more money to finance the journey (De Haas, 2009), and an outright change of migration plans among others. It is believed that migrants have no intention of permanently settling down in their transit states or countries (Nielsen, 2008), although changes in circumstances make this happen while they are in transit.

De Haas (2009), argues that term 'transit migration' is misleading and ignores the emerging empirical evidence shows that migrants' journeys may take months or years and are generally made in stages.

\subsection{The return intentions of migrants.}

It is difficult to genarally ascertain the return intentions of migrant. Although most migrants originally intend on returning to their home countries after accomplishing their migration goals, other mitigating factors sometimes alter these intentions. For instance, starting a family in the host country.

The current literature on migration has paid little attention to the fact that many migrants return to their home countries after having spent a number of years in the host country. According to Adda, Dustmann and Mestres (2006), this is surprising given the fact that a greater proportion of the migrations today are in fact temporary.

In a study of the decision process underlying return migration in Germany, Adda et al., (2006) noted that in each period, migrants decide whether to stay in the host country or to return to home country, simultaneously with consumption and investment choices. The decisions are taken comparing the discounted flow of utility between staying for an additional year and returning to the home country permanently, and depend on the capital invested in each country as well as on a series of stochastic shocks (Adda et al, 2006). According to Van Baalen and Tobias Muller (2008), people revise their intention to return as the years go by until they return, proceed to another country or return home. 


\subsection{Theoretical background}

From the literature review done, there are many theories that have been elaborated in relation to international migration. Early researchers in this field grouped the migration theories into economic, demographic and sociological theories. Of these theories, the economic theories may add more value to this study than the others. The first in this category is the neoclassical macroeconomic theory which holds the view that migration is caused by differentials in the demand and supply of labour between nations (Massey et al., 1993). Hence places of high labour shortages would attract migrant labour from a place of abundance. The second category points to the neoclassical microeconomic theory which holds that the decision to migrate is rather determined on the micro scale by the individuals who decide to migrate to other countries judging from what they hope to gain from the migration process. A third category, "New economic theory" or "New economics of labour migration theory of migration" on its part holds that migration occurs because families or other social groups, in a bid to diversify their income earnings as well as risks, decide on some of their members to migrate. Yet the fourth category, "the Dual market theory of migration" believes that migration occurs because of wage differences between countries. Hence a low-wage migrants are attracted by relatively high-wage employment in other countries (Myron and Teitelbaum, 2001).

The most explicit and comprehensive theory of the aforementioned theories that is most relevant to this study is the migration network theory developed by Massey (Massey et al., 1993; Light et al., 1989). According to this theory, Massey et al. (1993) hold that migrations lead to the formation of networks which in turn feed subsequent migrations. This means that once migrations are initiated, networks are automatically formed and further migrations take place independently of the initial push and pull factors that cause the migration. Massey et al. (1993) advances two reasons how these networks support and promote further migration.

- Firstly, once migration has reached a certain threshold, they result in autonomous social structures which ease migration in the form of reduced social, economic and emotional costs involved in the process of migration. Hence networks act like some sort of "shock absorbers" in the migration process.

- Secondly, networks also support migration in the sense that they act as risk diversification for family members of those who migrate. This supports the views of the New Economic theory earlier discussed.

The precursors of the network theory also hold that migration gets to a stop at one point where there is what they term "economic saturation" where the job market in the mainstream economy of the receiving country is full. This then leads to what he calls "Flow-backs". This is because migrants find it more and more difficult to find jobs and accommodation. This is the point where other scholars like Light Ivan and others disagree (Ivan et al. 1987, 1989, 2004). On their part they hold that migrants do not only rely on their destination countries to get jobs but also create jobs for themselves through these same networks as he put it "networks either improve the efficiency of searches or increase the actual supply of opportunities or both". This is especially true among the street vendors in urban South Africa. This happens through immigrant entrepreneurship. Migrants, through their personal initiative and cooperative efforts to apply capital to the employment of themselves and of other immigrants (of the same origin) in their destination countries. This therefore counteracts the effects of economic saturation as postulated by Massey et al (1993).

This study employs the Migration Network theory developed by Massey. According to this theory, Massey and others hold that migrations lead to the formation of networks which in turn feed subsequent migrations (Massey et al, 1993; Light et al., 1989).

\section{Research Methodology}

\subsection{Research Design}

The research design is the guiding framework on how the researcher will get and analyse information. "It situates the researcher in the empirical world" (Keith, 1998). Hence, this research takes a quantitative dimension though there may be some aspects of a qualitative study. This is simply because there is hardly any social science research work that is strictly quantitative or qualitative (Bell, 2005). Since the research is based on the immigrant vendors and it is very difficult to study all of these vendors and whose sampling frame is not available, it is evident that the design is a cross-sectional one or "correlation survey" designs (Keith, 1998). In the absence of a sampling frame, the "purposive" was utilised. The sampling units (respondents/participants) were subjectively selected by the researcher on the site based on his knowledge. This was also combined with "snowballing" as some respondents directed the researchers to potential respondents who constituted part of the population of interest (immigrant vendor of African origin). 


\subsection{Population of study}

The population of interest in the study was that of immigrant street vendors from other African countries. The population was chosen by the researcher because of his interest in African migrants and also because they constitute the majority of poor immigrants in urban South Africa who depend largely on the informal sector in general and street vending in particular for their livelihoods.

\subsection{Study Sites}

The study was based in some suburbs of Cape Town. The sample was drawn from five main suburbs namely: Bellville, Parow, Wynberg, Mitchells Plain and the CBD (Cape Town Central). Some road junctions were also visited to select some participants. These sites were chosen based on the researcher's knowledge of the trading sites in Cape Town. Caution was however taken to avoid the "concentration bias" as the sites were sufficiently separated from each other.

\subsection{Instrument}

A semi-structured questionnaire was used to collect the data for this study. The questionnaire was made up of both closed-ended and open-ended questions. Open-ended questions were used in cases where a wide range of answers (mostly qualitative) was anticipated which were later categorized during the data analysis phase. The strategy of openended questions in the questionnaire instrument was used to get detail information about the past experiences (sort of narratives) of the respondents which are needed to test the hypotheses of the research (despite of this procedure not being common in quantitative studies).

\subsection{Data Collection}

The data collection process took place between 28th of June 2010 and the 13th of August 2010 during which a total of two hundred and eight (208) questionnaires were administered in the 5 conveniently selected main sites and other road junctions in Cape Town. The total of 500 questionnaires had been envisaged but this number could not be achieved mainly due to the time factor and logistical problems.

The administration of the questionnaires took the form of face-to face interviews with the respondent which necessitated some time and patience as it was done in the respondents' place of activity.

\subsubsection{Sampling}

The Sampling method used in the study was purposive where access to the respondent was through direct and indirect contact. Direct access was by the introduction of the subject matter to the potential respondent and the explanation of the raison d'être of the project to have his or her consent (as seen on the cover page of the questionnaire). Indirect access otherwise known as "snowballing" as mentioned earlier was used in especially when potential respondents appeared suspicious and skeptical of what we were out for. After the preliminary introduction by the third party (known respondent), the researcher then explained the whole process to the potential respondent to get his or her full consent. Respondents were selected subjectively on the sites while caution was taken to make sure there was no bias of any nature. There was no gender, nationality, age or other preferences (apart from ensuring that the potential respondent was an immigrant from any other African country. However, we were guided by the idea of representativeness of the sample.

\subsection{Methods of Analysis}

In order to answer the research questions, the following procedure was used in the data analysis. The Statistical Package for Social Science (SPSS version 19) was used to analyse the data and the analysis was basically descriptive as inferential statistics could not be used due to the lack of viable data on the study population as a whole. Hence the external validity of the instrument cannot be ascertained.

The general quality of the data collected can be said to be good as the rate of non-response was relatively low $(0.832 \%)$ judging from the fact that two hundred and eight (208) questionnaires out the initial two hundred and fifty questionnaires printed for the field work were effectively administered. 
The information from the questionnaires was first coded and entered into a database developed to this effect. During the process, the open-ended questionnaires were categorized following the responses from the field. The spatial migratory trajectories were traced from the type of transport means used to get into the country to determine whether they were direct or indirect as well as the number of countries the migrant passed through.

\section{Findings and discussion}

\subsection{General Characteristics of the Sample}

It is worth noting that 20 countries of immigrants are represented in the survey with three countries namely: Cameroon, DRC (Democratic Republic of Congo) and Zimbabwe being highly represented with $24.5 \%, 19.2 \%$ and $14.4 \%$ respectively of the sample of street vendors as displayed the bar chart.

Fig 1: Countries of birth of the street vendors

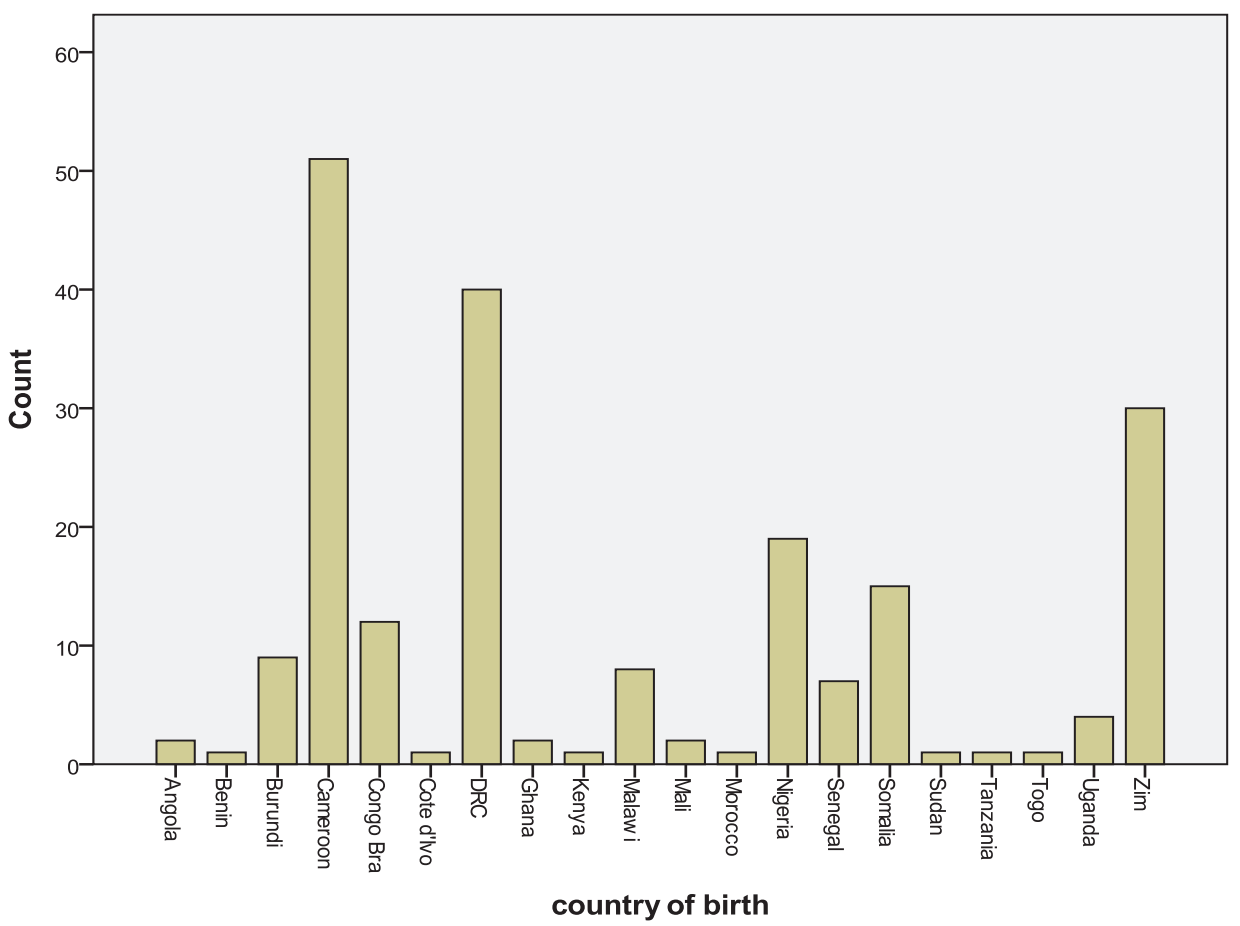

From the data gathered, the migration of Africans into South African cities increases sharply as the years go by. The number of migrant street vendors almost doubled between 1993 and 2002 and almost tripled between 2003 and 2007 while the marked increase actually started in 2004 (see fig. 2 below). This is ten years after the first democratic elections in the country in 1994. The stable political atmosphere probably played a role in making South Africa an attractive destination for many migrants especially from the African continent (Peberdy and Rogerson 2000). 
Fig 2 Curve shows the arrival of foreign street vendors

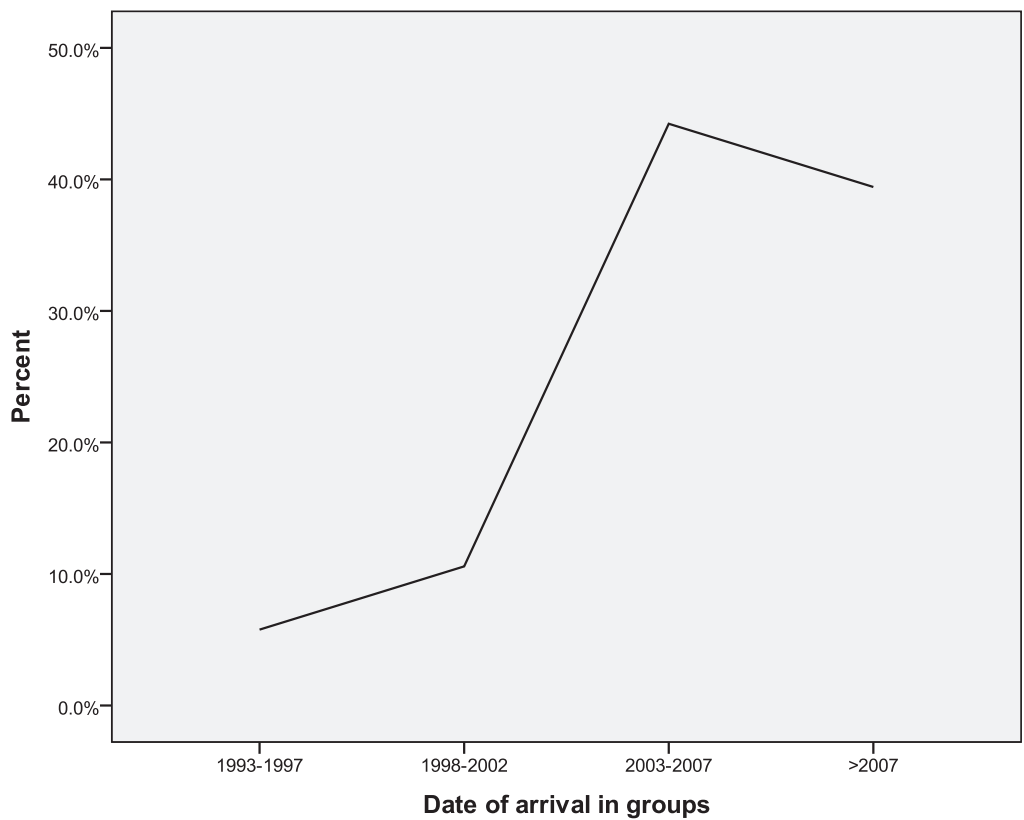

The continuous increase in the number of African immigrant into South Africa (figure above) can be attributed to the advent of democracy in the country from 1994 which also led to the opening of the country to the rest of the world coupled with the relaxation of laws (examples are the "move-on law" and the "urban areas act" of 1923) that hindered the development of the informal sector in general and street vending in particular.

\subsection{Spatial migratory trajectories of street vendor}

The actual migratory trajectory of street vendors shows that most of the vendors come to South Africa directly from their countries of birth. Among the 208 respondents interviewed, only 90 passed through other countries or have lived in other countries apart from their countries of origin. Hence $56.7 \%$ of the vendors had never lived in any other country or passed through one.

Table 1: Spatial migratory trajectory (direct or indirect)

\begin{tabular}{|l|l|l|}
\hline Stay/transit through other countries & Frequency & Percent \\
\hline Yes & 90 & 43.3 \\
\hline No & 118 & 56.7 \\
\hline Total & 208 & 100 \\
\hline
\end{tabular}

The results noted in table 3 above suggest that an overwhelming majority (50\%) of the street vendor interviewed came directly to South Africa and the air flight was the preferred mode of travel utilised.

\subsubsection{Nationality and spatial migratory trajectory}

Marked disparities exist between countries and regions of birth as concerns the migratory trajectories. The trajectories of the immigrant street vendors can best be analysed using table 4 and fig 2 below: 
Table 2: Nationality and spatial migratory trajectory

\begin{tabular}{|c|c|c|c|c|}
\hline \multirow{2}{*}{ Nationality } & & \multicolumn{2}{|c|}{$\begin{array}{l}\text { Stayed in another Country before } \\
\text { South Africa? }\end{array}$} & \multirow[b]{2}{*}{ Total } \\
\hline & & Yes & No & \\
\hline \multirow[t]{2}{*}{ Cameroon } & Count & 9 & 42 & 51 \\
\hline & $\%$ within Nationality & $17.6 \%$ & $82.4 \%$ & $100 \%$ \\
\hline \multirow[t]{2}{*}{ DRC } & Count & 21 & 19 & 40 \\
\hline & $\%$ within Nationality & $52.5 \%$ & $47.5 \%$ & $100 \%$ \\
\hline \multirow[t]{2}{*}{ Zimbabwe } & Count & 13 & 17 & 30 \\
\hline & $\%$ within Nationality & $43.3 \%$ & $56.7 \%$ & $100 \%$ \\
\hline \multirow[t]{2}{*}{ Nigeria } & Count & 7 & 12 & 19 \\
\hline & \% within Nationality & $36.8 \%$ & $63.2 \%$ & $100 \%$ \\
\hline \multirow[t]{2}{*}{ Somalia } & Count & 9 & 6 & 15 \\
\hline & $\%$ within Nationality & $60 \%$ & $40 \%$ & $100 \%$ \\
\hline \multirow{2}{*}{$\begin{array}{l}\text { Congo } \\
\text { Brazzaville }\end{array}$} & Count & 4 & 8 & 12 \\
\hline & $\%$ within Nationality & $33.3 \%$ & $66.7 \%$ & $100 \%$ \\
\hline \multirow[t]{2}{*}{ Burundi } & Count & 5 & 4 & 9 \\
\hline & $\%$ within Nationality & $55.6 \%$ & $44.4 \%$ & $100 \%$ \\
\hline \multirow[t]{2}{*}{ Malawi } & Count & 7 & 1 & 8 \\
\hline & $\%$ within Nationality & $87.5 \%$ & $12.5 \%$ & $100 \%$ \\
\hline \multirow[t]{2}{*}{ Senegal } & Count & 3 & 4 & 7 \\
\hline & $\%$ within Nationality & $42.9 \%$ & 57.1 & $100 \%$ \\
\hline \multirow[t]{2}{*}{ Others } & Count & 12 & 5 & 17 \\
\hline & $\%$ within Nationality & $70.6 \%$ & $29.4 \%$ & $100 \%$ \\
\hline Total & Count & 90 & 118 & 208 \\
\hline
\end{tabular}

Vendors from Cameroon, Congo Brazzaville and Nigeria have the least experience in migration as $82.4 \%, 66.7 \%$ and $63.2 \%$ of vendors from these countries respectively have never stayed in any other country other than their countries of birth even in the course of their migration to South Africa. This implies that their migratory trajectory to South Africa is a direct one. On the other hand vendors from Malawi as well as from Somalia show a high experience in migration as $87.5 \%$ and $60 \%$ respectively have migrated at least once before coming to South Africa. The case of Somalia is understandably due to long-lasting civil war in the country while the Malawian experience can be attributed to the high degree of cross-border trade within neighbouring Southern African countries.

\subsubsection{Means of travel to South Africa}

In terms of the means of transport that these immigrants use to reach their country of destination, this result confirms the preceding results in that suggested that $50 \%$ of the migrants entered the country by direct flight into the country.

Table 3 Means of travel to South Africa

\begin{tabular}{|l|c|c|}
\hline Mode of travel & Frequency & Percentage \\
\hline Vehicle & 91 & 43.7 \\
\hline Airplane & 104 & 50 \\
\hline Ship & 6 & 2.9 \\
\hline Foot & 7 & 3.4 \\
\hline Total & $\mathbf{2 0 8}$ & $\mathbf{1 0 0}$ \\
\hline
\end{tabular}

To capture the cross-country differences in the means of travel to South Africa, a cross tabulation was conducted as noted in table 4 below. 
Table 4: Nationality and Means of travel to South Africa.

\begin{tabular}{|c|c|c|c|c|c|c|}
\hline \multirow[b]{2}{*}{ Nationality } & & \multicolumn{4}{|c|}{ Means of travel to South Africa } & \multirow[b]{2}{*}{ Total } \\
\hline & & vehicle & airplane & Ship & foot & \\
\hline \multirow[t]{2}{*}{ Cameroon } & Count & 2 & 49 & 0 & 0 & 51 \\
\hline & $\%$ within Nationality & $3.9 \%$ & $96.1 \%$ & $.0 \%$ & $.0 \%$ & $100.0 \%$ \\
\hline \multirow[t]{2}{*}{$\mathrm{DRC}$} & Count & 25 & 15 & 0 & 0 & 40 \\
\hline & $\%$ within Nationality & $62.5 \%$ & $37.5 \%$ & $.0 \%$ & $.0 \%$ & $100.0 \%$ \\
\hline \multirow{2}{*}{ Zimbabwe } & Count & 24 & 0 & 0 & 6 & 30 \\
\hline & $\%$ within Nationality & $80.0 \%$ & $.0 \%$ & $.0 \%$ & $20.0 \%$ & $100.0 \%$ \\
\hline \multirow[t]{2}{*}{ Nigeria } & Count & 2 & 17 & 0 & 0 & 19 \\
\hline & $\%$ within Nationality & $10.5 \%$ & $89.5 \%$ & $.0 \%$ & $.0 \%$ & $100.0 \%$ \\
\hline \multirow[t]{2}{*}{ Somalia } & Count & 12 & 0 & 3 & 0 & 15 \\
\hline & $\%$ within Nationality & $80.0 \%$ & $.0 \%$ & $20.0 \%$ & $.0 \%$ & $100.0 \%$ \\
\hline \multirow[t]{2}{*}{ Congo Brazzaville } & Count & 2 & 10 & 0 & 0 & 12 \\
\hline & $\%$ within Nationality & $16.7 \%$ & $83.3 \%$ & $.0 \%$ & $.0 \%$ & $100.0 \%$ \\
\hline \multirow[t]{2}{*}{ Burundi } & Count & 6 & 1 & 2 & 0 & 9 \\
\hline & $\%$ within Nationality & $66.7 \%$ & $11.1 \%$ & $22.2 \%$ & $.0 \%$ & $100.0 \%$ \\
\hline \multirow[t]{2}{*}{ Malawi } & Count & 8 & 0 & 0 & 0 & 8 \\
\hline & $\%$ within Nationality & $100.0 \%$ & $.0 \%$ & $.0 \%$ & $.0 \%$ & $100.0 \%$ \\
\hline \multirow[t]{2}{*}{ Senegal } & Count & 0 & 7 & 0 & 0 & 7 \\
\hline & $\%$ within Nationality & $.0 \%$ & $100.0 \%$ & $.0 \%$ & $.0 \%$ & $100.0 \%$ \\
\hline \multirow[t]{2}{*}{ Others } & Count & 10 & 5 & 1 & 1 & 17 \\
\hline & $\%$ within Nationality & $58.8 \%$ & $29.4 \%$ & $5.9 \%$ & $5.9 \%$ & $100.0 \%$ \\
\hline \multirow[t]{2}{*}{ Total } & Count & 91 & 104 & 6 & 7 & 208 \\
\hline & $\%$ within Nationality & $43.8 \%$ & $50.0 \%$ & $2.9 \%$ & $3.4 \%$ & $100.0 \%$ \\
\hline
\end{tabular}

It can be seen from the table 4 that most of the immigrant street vendors from West and Central African countries such as Senegal, Cameroon, Nigeria and Congo Brazzaville entered the country by direct flight from their countries of birth (96.1\%, 89.5\% and $83.3 \%$ respectively) On the contrary, vendors from the East and Southern African Countries such as the Democratic Republic of Congo (DRC), Malawi and Zimbabwe including Somalia travel to the country by road. This sometimes entailed spending weeks or even months in other countries during their transit. This is typically the case with immigrant vendors from Somalia where most of them usually pass through countries like Kenya, Mozambique, Malawi, Botswana and Zimbabwe before finally entering South Africa. This is also the case with some of the street vendors from DRC who had to pass through Angola, Mozambique and Zimbabwe. These trajectories could sometimes take months before they reach their final destination. This is also buttressed by the fact that the proportion of vendors who have stayed or passed through another country shows the same trend. We also notice the only vendors coming to South Africa on foot are those from Zimbabwe. This is perhaps due to the political turmoil in the country since 2007 coupled with its nearness to South Africa.

One can also notice from figure 2 above, a greater mobility of vendors from Southern African countries such as Malawi, Zimbabwe, and DRC with the exception of those from Somalia who are also very mobile. This is probably due to the unstable political atmosphere in Somalia. This mobility of the vendors could be explained by the effectiveness of strong social and migration networks as well as the effects of globalization and its impact on legislation governing migration in most countries today.

\subsubsection{Prospects for return or further migration}

The prospect of further migration of the vendors is largely positive with $76 \%$ of them indicating their intention to move with only $24 \%$ indicating their intention to stay permanently in the country as shown in table 5 below: 
Table 5: Further migration prospects

\begin{tabular}{|c|c|c|}
\hline & Frequency & Percent \\
\hline Yes & 158 & 76.0 \\
\hline No & 50 & 24.0 \\
\hline Total & $\mathbf{2 0 8}$ & 100.0 \\
\hline
\end{tabular}

However, a majority of those who intend to leave the country indicate the destination to be their countries of birth or origin. Numerous reasons were given by various immigrant street vendors for their intention to leave the country ranging from socioeconomic, through financial to socio-political problems. A majority of the vendors (58\%) who expressed their intentions leave the country said the reason was just that the host country was not their "home" country as some simply put it, "home is home". There was therefore a high proportion of 'return migrants' who hoped to return to their home countries to reunite with their family members and other loved ones. On the socio-economic domain, many of the vendors who intended to leave the country cited economic hardship as the main push factor as shown by the expressions "hardship", "not a better place" and "difficult here". This implies that they were finding it difficult to survive on their trade. Problems of insecurity like the fear of further xenophobic attacks like to the one that took place in 2008 in most informal settlements in the country were among the socio-political reasons of further migrations (the fear was greatly fanned by rumours that there were going to be such attacks again immediately after the 2010 FIFA world cup that was hosted by South Africa). Others just expressed their intentions to go to "better" places such as Europe, Canada or USA where they perhaps had family members and/or friends or anticipated better living conditions in these places.

Table 6: Some main reasons for decision on further migration

\begin{tabular}{|l|c|l|c|}
\hline \multicolumn{2}{|l|}{ Further migration intention } & No intention for further migration \\
\hline Reasons & $\begin{array}{c}\text { Approx. } \\
\text { percent }\end{array}$ & Reasons & $\begin{array}{c}\text { Approx. } \\
\text { percent }\end{array}$ \\
\hline Go back home & 58.2 & Family here & 14.0 \\
\hline Go to developed countries & 10.1 & No money & 12.0 \\
\hline Difficult living here & 7.0 & Better here/O.k here & 20.0 \\
\hline Insecurity & 3.2 & Kids' welfare \&education & 8.0 \\
\hline Xenophobia & 3.2 & Not yet achieved goal & 14.0 \\
\hline
\end{tabular}

However, a huge proportion of vendors who intended to migrate further were not certain about the date of migration (84.4\%).

On the other hand, having a family was the main reason keeping most the immigrants in the country as seen by expressions "education of my kids", "my partner/kid is here" and "family here" which meant they had the task of raising their family (especially children) in the country. Another proportion of the vendors gave their reason for not intending to leave the country as lack of financial means as seen by the expression "no money". These are immigrant vendors who wished to leave the country but lack the financial means that could permit them to either travel back to their home countries or start up an economic activity in a different country. This proportion probably forms part of the 'return migrants'. Another proportion the vendors (about 20\%) simply admitted that South Africa was the best destination for them and did not wish to migrate further. Hence they gave expressions such as "it is better here" and "good here". Yet, another proportion of the vendors did not intend to leave soon because they had not yet achieved their goals. This implies that they had well-defined goals and could only leave or return once the goals have been achieved. Perhaps this is the reason why a majority of those who intended to leave never had no fixed date of departure.

It would also appear that in as much as many of the immigrant vendors were intending to return "home", many equally never encouraged their relation to migrate to South Africa for various reasons. This can be seen from the number that had helped other prospective migrants to migrate into the country.

\section{Conclusion}

The aim of this study was to explore the spatial migratory trajectory of migrants to South African since 1994 with special emphasis on street vendors of African origin. The results of the study revealed that the migration of Africans into South 
African cities increases sharply as the years go by. The number of migrant street vendors almost doubled between 1993 and 2002 and almost tripled between 2003 and 2007 while the marked increase actually started in 2004. The stable political atmosphere probably played a role in making South Africa an attractive destination for many migrants especially from the African continent. The actual migratory trajectory of street vendors shows that most of the vendors come to South Africa directly from their countries of birth. Among the 208 respondents interviewed, only 90 passed through other countries or have lived in other countries apart from their countries of origin. Inter-country comparism revealed that vendors from Cameroon, Congo Brazzaville and Nigeria have the least experience in migration as $82.4 \%, 66.7 \%$ and $63.2 \%$ of vendors from these countries respectively have never stayed in any other country other than their countries of birth even in the course of their migration to South Africa. This implies that their migratory trajectory to South Africa is a direct one. On the other hand vendors from Malawi as well as from Somalia show a high experience in migration as $87.5 \%$ and $60 \%$ respectively have migrated at least once before coming to South Africa. In terms of the means of transport that these immigrants use to reach their country of destination, it was noted that $50 \%$ of the migrants entered the country by direct flight into the country. The prospect of further migration of the vendors was largely positive with $76 \%$ of them indicating their intention to move with only $24 \%$ indicating their intention to stay permanently in the country. This notwithstanding, a significant proportion indicated their willingness to return to their home countries one day.

On the basis of these results alone, one may suggest there is an association between the decision to transit and the preferred mode of travel. This association can be partially explained by the circumstances surrounding and motivating emigration as well as the urgency of travel, distance to be travelled and affordability. For instance, migrants under pressure to leave as in war scenery do not have the time or the financial means to plan their departures. The reverse is true for countries enjoying peace but experiencing economic pressures. Once in the South Africa, what are the chances that these immigrants will return to their home countries?

\section{References}

Adda, J., Dustmann, C \& Mestres, J. (2006). A dynamic model of return migration. Working paper, mimeo.

Bell, J.(2005). Doing your research project: A guide for first-time researchers in Education and Social science. 4th edition. Open University Press.

Crossa, V. (2009): "Resisting the Entrepreneurial City: street vendors" struggle in Mexico City's Historic Centre" in International journal of Urban and Regional Research, vol.331, Blackwell Publishing

Crush J. and McDonald David, D. (2000): "Transnationalism, African immigration and new migrant spaces in South Africa" in Canadian Journal of African Studies Vol. 34:1-19

De Haas, H. (2009). Trans-Saharan and Trans-Mediterranean migration: questioning the transit hypothesis. Paper presented at ESF SCSS Exploratory Workshop: The Human Costs of Border Control in the Context of EU Maritime Migration Systems, Vrije Universiteit Amsterdam, Netherlands, 25-27 October.

De Miguel-Liken V., Solana-Solana, M. and Pascual-de Sanset, A. (2009): "Migratory Trajectories and geography of the family of the foreign population in Spain" unpublished manuscript.

ILO (2002): Men and Women in the Informal Economy: A Statistical Picture. International Labour Organisation publication.

Kamala Sankaran et al. (n.d): "Street Vendors in India" in WIEGO Law Project on the Informal Economy: unpublished manuscript.

Keith Punch, F. (1998): Introduction to Social Research: Quantitative and qualitative approaches. SAGE publications.

Lund, F. (1998): Women street vendors in urban South Africa: A synthesis of selected research findings CSDS research report no. 15. University of Natal.

Lund, F et al. (2000): Street trading. School of Development studies, University of Natal.

Light I. (2004): "Immigration and ethnic economies in giant cities" in 2004 UNESCO Publication, Blackwell publishing Ltd.

Light I., Bhachu, P. \& Karageorgis, S. (1989): "Migration Networks and Immigrant Entrepreneurship" in California Immigrants in world perspective: The Conference papers vol. v- 1989-90.

Massey D.S., Arango J., Hugu G., Kouaouc A, Pellegrino A \& Taylor J.E, 1993. Theories of International Migration: A Review and Appraisal. Population and Development Review. (19): 3: 431-466, September.

Myron W. \& Teitelbaum M.S. (2001): Political Demography, Demographic Engineering, Berghahn Books

Nielsen, K. (2008). Migration policy, Development \& Transit migration. Unpublished Master's Thesis, University of Copenhagen.

Peberdy, S and Rogerson, C. (2000): "Transnationalism and Non-South African Entrepreneurs in South Africa's small, medium and Micro-Enterprise (SMME) economy" in Canadian Journal of African studies, Vol. 34(1), Canadian Association for African studies.

Pécoud A. (2005): "Les enjeux de l"entreprenariat immigré" in Journal of international migration and integration, vol.6, no 4.

Polzer, T. (2008): "Migrant employment in South Africa: New data from the Migrant Rights Monitoring Project" in Migrant experiences within the South African labour market ed. Simona Galo-Mosala, pp 35-50. Scalabrini Centre of Cape Town.

Schapendonk, J. (2012). Turbulent Trajectories: African migrats on their way to the European Union. Societies, (2):27-41.

Sorensen, N. N. (2006). Mediterranean Transit Migration and Development: Experience and Policy Options. In: Sorensen (Eds). Mediterranean transit migration, Danish Institute for International Studies, Denmark. Available at: www.diis.dk. 
Tengeh, R.K., Ballard, H. \& Slabbert, A. (2011). A Framework for Acquiring the Resources Vital for the Start-up of a Business in South Africa: an African Immigrant's Perspective, European Journal of Social Sciences, 23 (3): 362-381.

Vicki R. (2005): "City Squeezes Soul from Trade" in Mail and Guardian of July 22-28.

Zuberi T. \& Sibanda, A. (2005):"Migration and employment" in Zuberi, Sibanda \& Udjo (Eds). The Demography of South Africa. M.E Sharpe, New York. 
